\title{
In-Depth Analysis of PC Industry in China
}

\author{
Xiaojun Cui \\ Department of Business Administration, Guangdong Radio and TV University \\ Guangzhou 510091, China \\ E-mail: xjcui@gdrtvu.edu.cn
}

\begin{abstract}
Personal Computer (PC) industry in China has experienced a rapid growth in China in recent years, and has played a more and more important role in the national economy. This motivates us to analyze the business environment and strategic situation of the PC industry in depth. A PEST analysis is carried on to analyze the business environment of the PC industry, and Porter's five forces analysis is used to analyze the competitive nature of PC industry in China.
\end{abstract}

Keywords: China's PC industry, PEST Analysis, Porter's Five Forces Analysis

\section{Introduction}

The aim of this paper is to analyze the business environment and strategic situation of personal computer (PC) industry in China. The motivation of an in-depth analysis of PC industry in China stems from the fact that PC industry has played a more and more important role in national economy of China, and has an important effect on the society. Since the emergence, PC has become a necessary tool in daily life in the society. Moreover, with the advances of technology, PC carries more and more functions and attracts more and more users. Now the PC market is mature and close to saturation in the developed countries, while the development of PC industry is still experiencing a rapid growth in the developing countries such as China.

Formed in the early period of 1990s, China's PC industry has only a short history. But the PC industry has been experiencing a rapid growth in the past fifteen years in China. Now PCs are common in families located in big cities of China, such as Beijing and Guangzhou. Even in small cities and rural districts, PCs are becoming more and more popular, and are more accessible. China has become an important PC market in the Asia Pacific area and even in the world. China's PC industry not only attracts many foreign PC makers to enter the market of China, but also fosters the world-class local companies to enter the global PC markets. The rapid development of PC industry also brings along the development of relevant industries, and PC industry has high impacts on the national economy.

This paper is devoted to analyzing the business environment and strategic situation of the PC industry in China. In particular, a PEST analysis and Porter's five forces analysis are used in the paper. The rest of the paper is organized as follows. In Section 2, the background, size, developments of the PC industry in China over the past few years are reviewed, and a PEST analysis is used to analyze the political, economic, social and technological issues in the PC industry of China considering both the moment and future implications. In Section 3, Porter's five forces analysis is used to analyze the competitive nature of PC industry in China, and the competitors within the PC industry in China and their strategies are identified. Findings of the paper are summarized in Section 4, and based on the findings, the strength of the PC industry in China at the present time and thoughts for the future success are analyzed.

\section{Analysis of industry sector}

\subsection{Introduction of the PC industry in China}

In this section, the analysis is focused on the status quos of China's PC industry including size, development and background over past few years and the prospects in the future.

In the recent years, the PC market in China kept a rapid growth especially from 2002 to 2006 . The growth of global PC market has been slowed down in the recent years but the growth in Asia especially in China is still very rapid. The PC market in China has experienced an average growth rate about $15 \%$ annually compared with that the growth of global PC market. The center of the development of PC market has been gradually transferred from the developed countries with mature market to the developing countries with great growth potentiality like China.

According to the report of IDC in 2006, the sales quantity of PC in China's market is 21.9 million sets and increased $15 \%$ than that of last year. With several years' development and growth, the size of China's PC industry increases continuously and rapidly. According to the report of IDC, China's PC market has become the biggest market in the 
Asia-Pacific area and accounted for 49\% market share in this area in 2006. IDC forecasts that China's PC market will keep the rapid growth and provide lots of market opportunities in the next five to ten years, because now PC is only popular in the big cities of China and the markets in small cities and countries still has great potentiality for growth. According to the forecast of IDC, the annual compound growth rate of China's PC market will be about $11.7 \%$ in the next five years and continue to keep the No.1 PC market in the Asia-Pacific area. And the sales quantity of PC in China is forecasted to be 32.94 million sets in 2010. This shows that the rapid growth of China's PC market will continue to provide the PC makers with great market opportunity in the next five to ten years. Compared with the low growth rate in the mature market of the developed countries, the development of PC industry in the developing countries like China is the main force to drive the development of global PC market.

Despite that China's PC market has been keeping a rapid growth, the homogeneity of the current PC products in China's market is more and more obvious. So the competition between the PC manufacturers is more and more drastic and price reduction has gradually become the important tool for PC manufacturers to compete for gain market share, which greatly influences the profit space of the PC manufacturers. For example, the price competition launched by Lenovo and Dell in China's market this year greatly lowers the PC price and reduces the profits of most of PC manufacturers (Shen and $\mathrm{Su}$ 2006). In order to keep the stale growth of the profit, the PC manufacturers begin to concentrate on how to control the internal operation costs. And the reduction of the profit space for PC manufacturers has a negative effect on their relationships with channel partners. So the innovation and development of the channel will play a significant role in China's PC market for the PC manufacturers.

In current PC market of China, the PC-density in the main big cities such as Beijing, Guangzhou, Shanghai and Shenzhen is very high and close the level in the developed countries but the PC-density in the small cities and countryside is still very low. So the construction of the market in small cities and countryside has been the major work in China's PC industry. With the continuous emergence of game PC, PC for internet bar, safe PC, PC for the middle and small size enterprises and media center PC products aimed at the special markets, the subdivision of PC has become a kind of trends (ICXO, pp. 13, 2006). And with the gradually familiar with the PC products, the application of PC will take place of performance to become the critical factor cared by the customers. So the subdivision aimed at the different applications naturally becomes the effective and important method for the PC manufacturers to improve their self competitiveness.

\subsection{A PEST analysis of China's PC industry}

A PEST analysis including political factors, economic factors, social factors and technological factors is used to analyze the PC Industry.

\subsubsection{Political factors}

Political factors have an important effect on the macro environment of industry development. The political environment is very stable in China. After the reform and openness in the late 1970s, the government in China has devoted to create a stable political environment to drive the development of economy and the construction of the state. On the one hand, the political environment in the domestic society of China is very stable and in the international community, China maintains good relationships with the neighboring countries and the big countries in the world. These show that China's government attaches importance to the stabilities of political environment. The stable political environment has attracted many foreign enterprises to invest in China in the past twenty years. Almost all the main foreign PC makers have entered the market of China through direct investment. As a big country playing more and more important role in international politics and economy, China's government is expected to continue to maintain the stability of the political environment.

China is in the transition process from the past planned system to the market economy system. The government of China has greatly reduced the direct interventions in the development. The development of industry is not planned by the government and is based on the needs of the market. On the other hand, with China's joining into WTO, China' government has gradually released the restrictions of many industries. Free development and competition is encouraged by the government and the government is trying to reduce the effect of the policy on the development of industry. Without the government interventions ad policy restriction, the communication and cooperation in PC industry is enhanced. The entry of foreign PC makers brings with the technologies and experiences so that drives the development of PC industry in China. As an open industry in China, China's government will continue to drive the internationalization of PC industry through communication and cooperation.

Compared with the market in the developed countries, the law and regulations in China are still not perfect. This weakness to some degree may have a negative effect on the development of the industry. But China's government has realized the importance of laws and regulations, and devoted to establish and perfect the laws and regulations in China. So the laws and regulations in China are expected to be gradually perfected in the future. 


\subsubsection{Economic factors}

Economic environment has an important effect on the development of industries and companies, and economic development can drive the development of industry. In the past few years, China's economy has been keeping a rapid growth and China has become the sixth biggest country in the world measured by GDP. Foreign trade and foreign direct investment are the forces to drive the development of economy in China. And the rapid growth of China's economy has driven the development of the industries in China. It has been mentioned in the previous sections that the PC industry in China is experiencing rapid development in China resulted from the rapid growth of China's economy.

Resources and low-cost labor forces are the advantages of China to develop the economy. So the manufacturing industry is the emphasis in China's economy development and plays an important role in national economy of China. More and more foreign enterprises transfer their production to China and invest in China to set up factories. With the increase of foreign direct investment and development of foreign trade, China's economy is expected to continue to keep rapid growth in the future. And the good economic environment will lead to the continuous development of the industries in China, especially the manufacturing industry. PC industry is expected to keep growing in the future influenced by the good economy development prospects in China.

On the other hand, the rapid development of economy in China has greatly improved the living standard and consumptive power of people in China. China not only has been the large product base in the world, but also has been a big consumptive market in the world. More and more foreign enterprises are entering the market of China not only for the low-cost labor forces but also for the big market. The increasing consumptive power of the people in China also drives the development of economy and industry.

\subsubsection{Social factors}

Social and cultural factors also have an important effect. In the early periods of the development of PC industry in China, PC was only used in the companies and was looked as a tool in the work. But with the development of economy and society, PC began to enter the life and home of people. PC has been more and more used in the home of China for study, entertainment and communication.

The development of the internet also drives the development of PC industry. In China, PC industry is related to the development of internet. The emergence of the internet changes the whole society and people's lives. Newspaper, radio and television are the main tools used by the people in the past of China. In the traditional culture of China, these traditional media are more likely to be accepted by the people in China. People are accustomed to know the news through reading newspaper and listening to the radio, and rest for leisure and fun through watching TV. But the emergence of PC and internet completely changes people's lives. All the information and news can be easily understood through the internet and people can use PC and internet for work and entertainment. So PC and internet make the world smaller.

As PC is gradually accepted by the social culture in China, PC begins to be used by more and more people in China and has an important effect the society and people's lives in China. PC has become a necessary tool to the people in China. So people have strong interest in the products of PC and more and more home user and enterprise users buy PC in China. Now PC-density in big cities of China is very high, but the growth of PC industry is still very rapid. On the one hand, the market in the small cities and countryside has big potentiality, because the people in small cities and countryside in China began to realize the use and importance of PC and have the potentiality to buy PC products. On other hand, young people and children in China are growing under the influence of PC and internet, so they also have the potentiality to buy PC in the future. PC is expected to play a more and more important role in the society and people's lives in the future.

\subsubsection{Technological factors}

$\mathrm{PC}$ is a kind of technological products and technological innovations have an important effect on the development of PC industry. When PC emerged in the market, the price is very high and it costs much for people to buy a PC. So the high cost in the early periods restricted the development and popularity of PC in China. But with the development and innovation of the technology, the cost of PC has been greatly reduced. PC has been a normal commodity in China that can be afforded by most of people. On the other hand, the quality of PC products is continuously enhanced by technological innovations. The technologies of PC develop very fast that generally faster and stronger PC is promoted to the market every year. The development of technologies leads to the fast update of PC products and the consumers can use the PC with newest technologies soon. So the technological development and innovation makes the price of PC cheaper and the quality of PC better. Technological development and innovation is an important factor to drive the development of PC industry.

Now PC has been the important part of people's work and life. PC is not a simple product and will be endowed with more and more functions to meet the individual needs of the consumers in China. In the next five to ten years, the Digital Home will experience rapid growth and home PC will become the management center for many tasks including 
entertainment, calculation, office, communications and management. The continuous emergence and application of new technologies will offer the consumers in China more innovative PC products. So in the next five to ten years, with the rapid growth, PC market in China will show the trend for diversified development. The new technologies and new product ideas will be the development trend in the future PC industry of China.

Moreover, the sell and distribution is changed by the technological innovations. In the past, PC only can be sold to the consumers in the shop through a face-to-face way. But the emergence of internet has changed this mode that the consumers can directly buy the PC products via internet or phone. Although this mode is not popular and extensively accepted by the consumers in China, this mode renovates the sell and distribution mode of PC and provides the consumers with more choices to buy PC products. This new mode of distribution is expected to be adopted by more and more consumers in China and drives the development of PC industry in the future, because this technological innovation not only provides an easier way for the consumers to buy PC, but also reduces the cost of PC makers.

\section{Evaluation of the competition in China's PC industry}

In this section, the competition in China's PC industry is evaluated including the competitive nature of the industry, and the competitors and their strategies to face competition.

\subsection{Porter's five forces analysis}

Michael Porter has identified five forces that are widely used to analyze the structure of any industry, and these five forces include bargaining power of suppliers, bargaining power of buyers, threat of new entrants, threat of new entrants, threat of substitutes and rivalry among competitors (Porter, 1980).2.3.1 International investment The foreign non-life insurance companies could provide Chinese and foreigners with any non-life insurance service in two years since the China's WTO accession. The foreign life insurance companies are authorized to provide the Chinese and foreigners with individual (non-group) life insurance service since the WTO accession. In three years they are permitted to provide health insurance, group insurance and premium or annuity service for Chinese and foreigners.

\subsubsection{Bargaining power of suppliers}

PC is a special product and the bargaining power of suppliers is very strong. Generally the PC makers don't have the core technologies of the input like CPU. The input of CPU decides the quality and functions of the PC, and the cost of CPU to a large extent determines the price of PC and has a significant effect on the profitability of PC products. CPU is the core input of PC and it is the high-tech product that there are only two providers of CPU in the world including Intel and AMD and. The production of PC is based on the CPU, and the innovation of CPU determines the upgrade of the PC. In fact, the biggest profit in this industry is earned by the CPU provider and the PC makers have to increase their profits by expanding the scale because the profitability of PC is low.

So the bargaining power of CPU providers is very strong to the PC makers. PC makers must cooperate with the CPU providers and obtain the supports from the providers. Without CPU, PC makers can not produce any type of PC. Based on the core input of $\mathrm{CPU}$, they can endow the $\mathrm{PC}$ with different designs and increase the additional functions of the PC. The cost of CPU determines the price of PC. Generally the innovation and upgrade of CPU will cut down the cost of $\mathrm{CPU}$ and then reduce the price of PC. Although other inputs providers have a weak bargaining power with PC makers, the providers of $\mathrm{CPU}$ - the core input of $\mathrm{PC}$ have a very strong bargaining power.

\subsubsection{Bargaining power of buyers}

The bargaining power of buyers is also very strong in the PC market of China. In the early period, PC is a kind of unique products and produced by few PC makers. With many years' development, PC has been a normal product and there are many PC makers in China including both local PC makers such as Lenovo and Founder and foreign makers such as Dell, HP and IBM. So in China, the consumers have many choices. Although the PC makers can endow their products with different designs and different functions, it is evitable that all the PC products are similar to the consumers. The price and brand are the most important factors to affect the purchase behavior of the consumers.

In China, the PC market is not monopolized by few big PC makers and there are many PC makers that provide PC products to the consumers. PC products of different makers are homogeneous to the customers in the market. Price has been the most important tool for the PC makers to compete for the consumers in China's PC market. PC makers in China don't have bargaining power to negotiate the price with the consumers. In fact, the drastic competition has leaded to the great decline of PC price in the market of China. Price has been the most important for PC makers to attract the consumers in China. So the bargaining power of buyers in China's PC industry is very strong and the PC makers in China have to face the drastic price competition.

\subsubsection{Threats of new entrants}

The threats of new entrants in China's PC industry are small. There are few barriers for new companies to enter PC industry in China. The government of China does not restrict the new entrants of PC industry for both local and foreign companies. The PC is not unique and the production of PC is easy to learn for the new entrants. The start-up cost of PC 
production is not very high. If a company has enough funds and obtains the support from input providers, they can easily enter the PC industry in China. And the simple PC products don't have high requirements on the technologies, so there are not technological barrier for new entrants of PC industry. And in PC industry of China, the consumers of PC products have little brand loyalty that it is easy for the consumers to know the brands and products of new entrants through lots of advertisements.

But it should be noted that economies of scale plays a very important role in PC industry of China and distribution channel is another important factor. The competition is very drastic for the PC makers in the PC market of China. Price competition has greatly reduced the profitability of PC makers in China and they have to survive in the competition depending on the scale. The current PC market has been dominated by some big PC makers of Lenovo, Dell, HP and Founder with big scale. So it is difficult for the new entrants to survive in the competition without the scale. On the other hand, it is difficult for the new entrants to access to the consumers in China' PC market, because the new entrants have to establish their own distribution channel in China. Channel is the critical factors to achieve the success in the market of China. The top PC makers in China have established their mature distribution channel and it is easy for them to sell their products to the consumers. For example, Lenovo has established its own distribution channel all over the China including the main big cities and other small cities and countryside. Therefore, although there are few barriers for new entrants in PC industry of China, economies of scale and distribution channel determines that it is very difficult for the new entrants to successfully enter the PC market of China and quickly hold a certain market share. So the threat of new entrants is small in the PC industry of China.

\subsubsection{Threats of substitutes}

The development of PC is greatly influenced by the technological development and innovation. PC has to face the big threat from substitutes with the development of technologies. Generally the technological products are more likely to be taken place by substitutes if they no longer have the unique functions to the customers. The emergence of PC completely changes the society and people's lives. But with the development of new technologies, some products have had the functions of PC and can be the substitutes for PC. With the development of digital television, the television is endowed with the functions of PC. Digital television combines the functions of both PC and TV that people can use the functions of PC through the television. Every home in China has the television and using digital television to enjoy the function of PC seems to be easily accepted by the customers in China. Moreover, the intelligent mobile phone also begins to have the functions of $\mathrm{PC}$ and it has the advantages of smaller size and convenience for carrying compared with the PC. So with the development of the technologies, many other products begin to have the functions of PC and become the potential substitutes for PC, and PC can not provide the unique functions to the customers in China. So the threat of substitutes to PC is big in China. But in order to reduce the threat of substitutes, PC makers have tried to enrich the functions of PC and provide the innovative PC products to the customers.

\subsubsection{Rivalry among competitors}

The rivalry among competitors in China's PC industry is very intense. Firstly, China's PC market is experiencing the rapid growth and the history of China's PC industry is short. Although Lenovo is current market leader, but many other firms in China including local firms and foreign firms are competing for the market leader. There are not rules of game in the PC industry of China and free competition is encouraged. The big PC makers don't try to control the market through the cooperation. With the rapid growth of the PC industry in China, every PC maker has the desire to become the market leader in this market.

Secondly, the PC products have become homogenous for all the PC makers in China. And there are high fixed costs of production for PC products. The large percentage of the cost to produce PC products is independent of the number of units produced so that PC makers are pressured to produce and sell larger volumes of products. According to these two factors, the PC makers in China have to compete in the market through cutting the price, which leads to the intense rivalry among the competitors in China's PC market.

Thirdly, customers can easily switch between the PC products in China. There are so many PC makers to provide PC products to the customers in China and the customers have many choices of PC provided by different firms. The brand loyalty of PC product in China is very low and it is easy for the customers to switch between the different PC products. So the PC makers in China have to try hard to compete for the customers and market share and the rivalry is very intense in China's PC industry. In the current PC market of China, other factors of brand and quality are not the critical factors because the development of PC industry is in the process of establishing brand and fostering the brand loyalty of the customers. So the price competition decides the intense rivalry in this industry of China.

\subsection{Main competitors and their strategies in China's PC industry}

There are many PC makers in the PC industry of China including the local firms and foreign firms. And among these PC makers, four main competitors exist in this market including Lenovo, Dell, HP and Founder: two local firms and two foreign firms. These four competitors have different strategies to compete and maintain their market share in the PC 
market of China.

\subsubsection{Lenovo}

As the biggest local PC maker in China, Lenovo has maintained the status of market leader for many years in the drastic market competition. The strategies of Lenovo are low price and brand.

On the one hand, low price is an important strategy for Lenovo to compete in the market. Low price helped Lenovo to become the market leader in China when Lenovo was still a small firm several years ago. In the past many years, Lenovo has been keeping up the strategy of low price. The strategy of low price made Lenovo easily to be known and accepted by the customers in China and rapidly increases the market share of Lenovo. The strategy of Lenovo is to expand the scale through low price, and then cut down the costs of production and reduce the price of PC through the economies of scale. Based on the biggest market share in China's PC market, Lenovo often presses its competitors and enhances its status of market leader through the price competition.

On the other hand, brand is another important strategy for Lenovo to attract the customers. As the no.1 PC brand in China, many people in China are proud of the rise of Lenovo. So the brand of Lenovo has an effect on the purchase behavior of the customers in China. Many customers in China buy the PC products of Lenovo to support the own brand of China. A strong brand has been established by Lenovo among the PC consumers in China. And Lenovo also has many orders from the governmental departments. Based on its national brand in China, government purchasing is an important market for Lenovo in China and the government purchases a great number of PC from Lenovo every year.

Moreover, Lenovo attaches importance to the markets in small cities and countryside. Based on its perfect distribution channel all over China, Lenovo can sell their products to any place in China. Lenovo has paid attention to the development of small cities and countryside when the PC makers are competing for the market share in main big cities in China. The perfect channel helps Lenovo to account for a large part of the market in small cities and countryside of China.

\subsubsection{Dell}

Different from other PC makers in China, Dell adopts its special direct distribution mode in China and this mode has helped Dell to succeed in the markets of many countries. Dell does not invest in establishing its own traditional distribution channel in China and it does not sell the PC through the traditional channel like shops. The strategy of Dell is to sell their PC products directly to the customers through the direct contacts with the customers via the internet or phone ( $\mathrm{Li}$ and Shi 2005). Dell expects to reduce the cost of PC products and provide a more convenient way for the customers in China to buy its products.

This strategy has helped Dell to achieve a certain success in the market of commercial PC in China, but this mode has faced many problems in the market of home PC, because this mode to some degree is contradicted to the consumer culture in China. The customers in China are more likely to purchase the products like PC in a traditional face-to-face way, and most of the customers are not willing to accept the direct distribution mode via internet or phone. So Dell's strategy is not successful in the home PC market of China. From last year, Dell also began to adopt the traditional distribution channel to combine with its direct distribution mode.

\subsubsection{Founder}

Founder is also a local PC maker in China, but the strategy of Founder is very different from Lenovo in the market. Founder does not have the support from the government purchasing and does not have a strong brand influencing power in the customers of China. So according to its self advantages, Founder focused on the development of enterprise clients. In terms of the various needs of the enterprise clients, Founder designs and develops different kinds of PC for the commercial use such as the PC for the special use of finance and invoice. PC is a large market in China and it is very important to develop the diversified markets. Founder is very clear about its strength and its strategy is to become the leader in the diversified market of enterprise clients. This strategy makes it not necessary for Founder to participate in the drastic price competition in the PC market and Founder can concentrate their resources on serving the diversified market of enterprise clients. Designing and developing the PC products according to the practical needs of the enterprises endows Founder with the competitive advantages with other PC makers in the market of enterprise enterprises. And this strategy has helped Founder to become the leader in this diversified market of enterprise clients.

\subsubsection{HP}

HP entered the PC market of PC relatively relate compared with other main foreign PC makers, but its market share increases fast and HP has achieved an important market position in China. HP adopts the different strategies in the different markets of high-end users and low-end users.

In the market of high-end users, the strategy of HP is to provide the PC products with high quality. HP has a good reputation in the international market and this reputation also makes the local users in China to believe in the quality of the products of HP. In HP provides the PC with high quality and good stability to its high-end clients, because HP 
knows that quality and stability, rather than price, are the most important factors to influence the purchase behavior of high-end users. This strategy has HP to achieve a big market share in the market of high-end PC users.

In the market of low-end users, HP adopts the strategy as follows. In this market, the market leader, Lenovo, has the absolute influencing power and HP follows all the strategies and activities of Lenovo in this market. When Lenovo cuts the price to promote its products, HP also follows Lenovo to cut the price of its products. This following strategy reduces the profitability of HP's PC products, but greatly increases the market share of HP. This strategy leads to the rapid increase of its market share in China's PC market, though HP entered the PC market of China later.

\section{Conclusions}

Based on the analysis in the report, it is founded that PC industry in China has experienced fast development in the past five years and the size of the market continues to increase. Compared with the low growth rate in the mature markets of the developed countries, China's PC industry is forecasted to keep rapid growth in the future and China's PC market has accounted for the biggest market share in the Asia-Pacific area.

The stable political environment and good economic environment in China have a good effect on the development of PC industry in China. And PC is more and more accepted by the people in China and PC has played a more and more important role in the society and people's lives of China. This also drives the development of PC industry and the potentiality to buy PC products in China. Moreover, the development of technologies also drives the development of PC industry in China, because the technological development and innovation in PC gradually reduces the price of PC and provides more innovative products to the customers in China, and the innovation in the distribution channel enriches the ways for the customers in China to buy PC.

The Porter's five forces analysis shows that the bargaining power of suppliers and bargaining power of buyers in China's PC market is both very strong. The threat of new entrants is small but the threat of substitutes is big. The rivalry among the competitors in China's PC industry is very intense because of the short history of China's PC industry, the homogeneity of PC products and the low brand loyalty of the PC consumers in China. The analysis shows that the competitive force in the PC industry of China is very strong, which has a positive effect on the long-term development of China's PC industry.

Lastly, there are four main competitors in the PC industry of China. These four competitors adopt different strategies in the market and drive the development of PC industry in China. As the biggest local PC maker in China, Lenovo has become the market leader in China's PC industry based on the strategy of low price and local brand. Dell has the strategy of adopting its special direct distribution mode in China. This strategy has helped Dell to succeed in the commercial PC market of China but not in the home PC market of China. As a small local PC maker, Founder just focused on the diversified market of enterprise clients and concentrates all their resources on designing and developing the PC products according to the needs of enterprise clients. This strategy has helped Founder to achieve the status of leader in this diversified market of China. Lastly, HP adopts different strategies in the market of high-end users and the market of low-end users. In the market of high-end users, the strategy of HP is to provide PC with high quality and good stability to the users, while in the market of low-end users, the strategy of HP is to follow the strategies and activities adopted by Lenovo, the market leader in the PC industry of China.

\section{References}

Burt, G., R. Bradfield, G. Cairns, K. Heijden, and G. Wright. (2006). The Role of Scenario Planning in Exploring the Environment in View of the Limitations of PEST and Its Derivatives. Int. Studies of Mgt. \& Org, 36 (3):50-76.

Burt, G., R. Bradfield, G. Cairns, K. Heijden, and G. Wright. (2002). The Sixth Sense: Accelerating Organizational Learning with Scenarios. Wiley, Chichester.

Haberberg, A., and A. Rieple. (2001). The Strategic Management of Organizations. Pearson Education Limited, Essex.

ICXO. (2006). The Analysis Report of PC Market in China. The Information Center of World Managers, Vol. 5, pp. 12-16.

Kippenberger, T. (1998). Strategy according to Michael Porter. The Antidote, 3 (6): 24-25.

Li, Y., and D. D. Shi. (2005). The Local Research of Dell's Direct Selling Mode. Commercial Economy and Management, 8: 23-25.

Luffman, G., E. Lea, S. Sanderson, and B. Kenny. (1996). Strategic Management. Blackwell, Oxford.

Paul, F. (2000). Strategic Management: An Introduction to Business and Corporate Strategy. FT Prentice Hall

Porter, M. E. (1980). Competitive Strategy: Techniques forAnalyzing Industries and Competitors. MacMillan, London.

Porter, M. E. (1998). The Competitive Advantage of Nations. London: MacMillan, London.

Shen, J., and M. Y. (2006). The Price Competition between Dell and Lenovo in China. Newspaper of International 
Finance, July 29, 2007.

[Online] Available: www.IDC.com.cn (Retrieved from 22 May 2007)

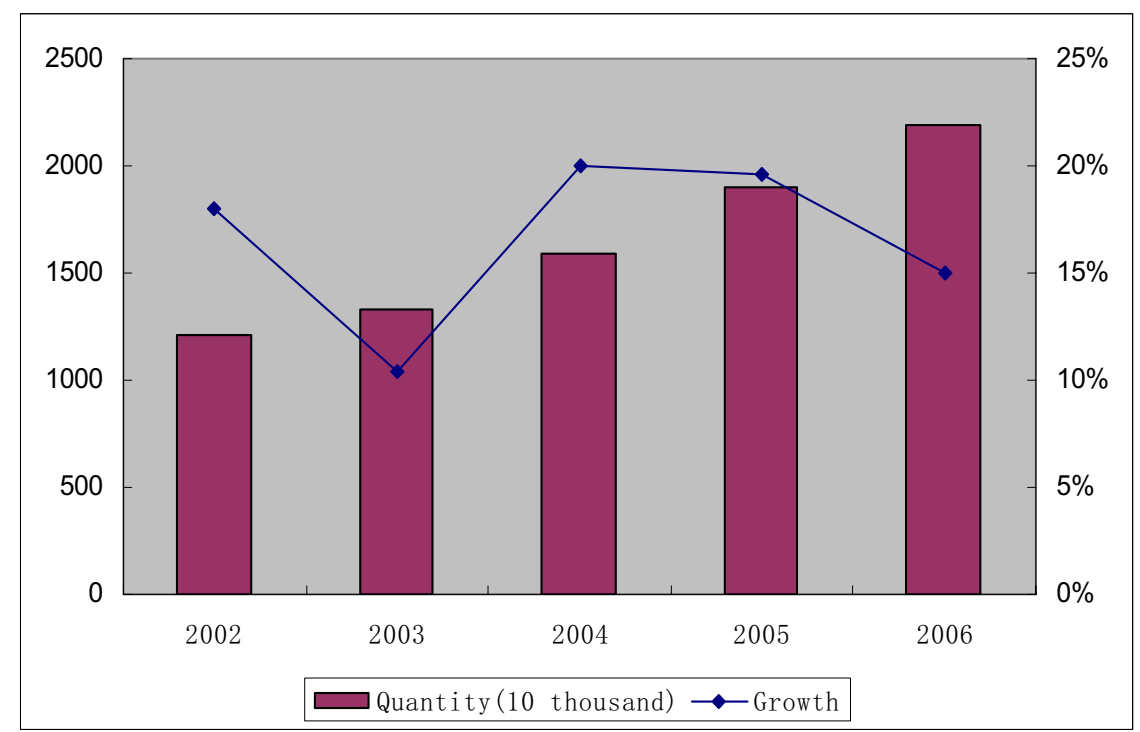

Figure 1. Statistics of PC Sales in China (2002-2006) (Data Source: IDC)

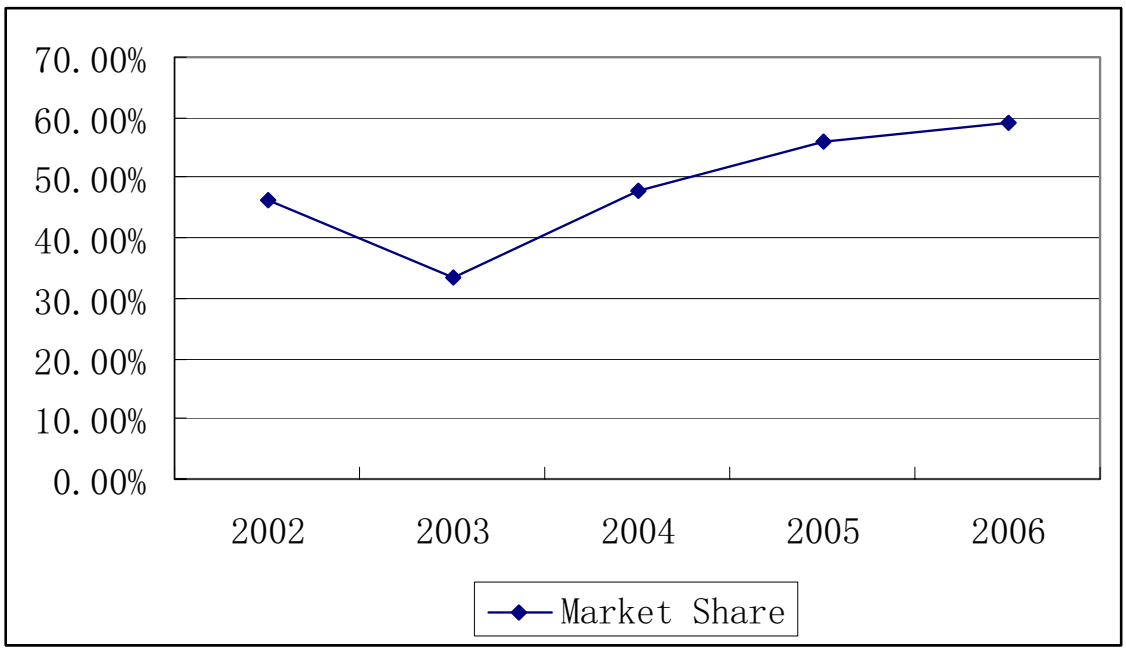

Figure 2. Market Share of China's PC Market in Asia-Pacific Area (Data Source: IDC)

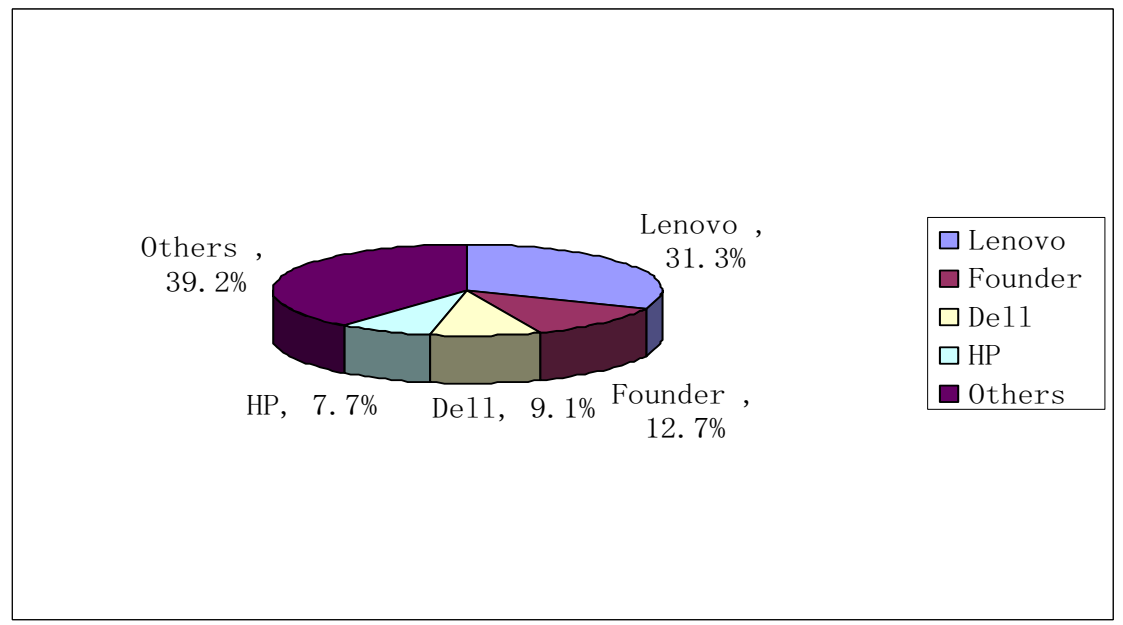

Figure 3. Market Share in the PC Market of China (2006) (Data Source: IDC) 